\title{
PENGARUH MODEL PEMBELAJARAN POE TERHADAP KEMAMPUAN PEMAHAMAN KONSEP IPA SISWA SD
}

\author{
Yogi Setya Novanto1), Rien Anitra1), Fajar Wulandari'1) \\ 1)Departemen Pendidikan Guru Sekolah Dasar, STKIP Singkawang, Singkawang, Kalimantan Barat, Indonesia \\ Corresponding author: Rien Anitra \\ E-mail : anitrarien@gmail.com
}

Diterima 04 Mei 2021, Direvisi 11 Mei 2021, Disetujui 21 Mei 2021

\begin{abstract}
ABSTRAK
Penelitian ini bertujuan untuk mengetahui pengaruh penggunaan model pembelajaran POE (Predict, Observe, Explain) terhadap kemampuan pemahaman konsep IPA siswa pada materi panas dan perpindahannya. Penelitian ini dilaksanakan di MIS Ushuluddin Singkawang. Jenis penelitian yang digunakan yaitu penelitian kuantitatif dengan metode quasi experimental design, dengan bentuk desain post-test only control design. Populasi dalam penelitian ini adalah seluruh siswa kelas V MIS Ushuluddin Singkawang. Sampel diambil menggunakan teknik purposive sampling. Setelah pengambilan sampel, yang terpilih menjadi kelas eksperimen adalah kelas VA dengan menggunakan model pembelajaran POE dan VB sebagai kelas kontrol yang menggunakan model pembelajaran langsung. Hasil penelitian menunjukkan bahwa: (1) Terdapat pengaruh kemampuan pemahaman konsep IPA siswa antara kelas yang diberikan model pembelajaran POE dengan kelas yang diberikan pembelajaran langsung pada materi panas dan perpindahannya di kelas V MIS Ushuluddin Singkawang; (2) Terdapat perbedaan kemampuan pemahaman konsep IPA siswa antara kelas yang diberikan model pembelajaran POE dengan kelas yang di berikan model pembelajaran langsung pada materi panas dan perpindahannya di kelas V MIS Ushuluddin Singkawang.
\end{abstract}

Kata kunci: model pembelajaran POE; kemampuan pemahaman konsep.

\begin{abstract}
This study is aimed at learning the influence of the use of the POE learning model (Predict, Observe, Explain) on a student's ability to understand science concepts on hot matter and transmigration. The study is carried out at MIS Ushuluddin Singkawang. The kind of research used was quantitative research with experimental quasi design. With a design post-test only design control. The population in the study are all the students in the V MIS Ushuluddin Singkawang class. The sample was taken using an additive sampling, after taking the selected sample into a VA class experiment which was an experimental class using the POE and VB control class that use a direct learning model. Research concluded that: (1) there is an influence on a student's ability to understand natural science between a class given by the POE learning model and a class given direct learning on hot matter and transfer to V MIS Ushuluddin Singkawang class; (2) there is a difference in the ability to understand a student science concept between the class given by the POE learning model and the class provided the direct learning model for hot matter and transfer to V MIS Ushuluddin Singkawang class.
\end{abstract}

Keywords: POE learning models; the ability to understand concepts.

\section{PENDAHULUAN}

IImu Pengetahuan Alam (IPA) merupakan ilmu yang berkaitan dengan alam dan lingkungan sekitar. Menurut Pt et al. (2013: 1-2) "IPA adalah pengetahuan manusia tentang alam semesta yang benar dalam arti rasional dan objektif". Benar dalam arti rasional, artinya sesuai dengan logika atau masuk akal dan objektif artinya dapat diuji kebenarannya secara ilmiah, tidak hanya berdasarkan pendapat seseorang saja tanpa dapat diamati kebenarannya oleh alat indera ataupun dengan eksperimen-eksperimen tertentu. $\mathrm{Hal}$ ini menunjukan bahwa IPA merupakan ilmu yang mencari tahu tentang pengetahuan alam secara sistematis sehingga IPA bukan hanya penguasaan kumpulan pengetahuan yang berupa fakta-fakta, konsep-konsep atau prinsipprinsip, tetapi juga merupakan suatu proses penemuan. Pentingnya pelajaran IPA di SD menjadikan siswa untuk berpikir secara positif yang memberikan dampak baik sehingga siswa menjadi tahu tentang teknologi dan ramah lingkungan sebagai elaborasi dari membaca IPA (Mariana \& Praginda, 2009: 6). Pembelajaran IPA pada anak SD juga 
mengajarkan cara memecahkan masalah, melatih kemampuan pemahaman, mengambil kesimpulan, melatih bersikap objektif, bekerja sama dan menghargai pendapat orang lain. Salah satu kemampuan yang perlu diperhatikan pada pembelajaran IPA adalah kemampuan pemahaman konsep IPA di SD.

Kemampuan pemahaman konsep adalah kemampuan yang menjelaskan suatu pengetahuan atau konsep dengan kata-kata sendiri dan dapat mengartikan atau menarik kesimpulan dari penjelasan yang bisa berupa huruf, angka, gambar dan sebagainya. Menurut Anderson \& Krathwol (2010: 106-114), ada tujuh indikator aspek pemahaman diantaranya: 1) Menafsirkan, yaitu mengubah informasi dari satu bentuk kebentuk lain; 2) Mencontohkan, yaitu proses identifikasi ciri-ciri pokok dari konsep atau prinsip umum; 3) Mengklasifikasikan, yaitu melibatkan proses mendeteksi ciri-ciri atau pola-pola yang sesuai dengan contoh, konsep atau prinsip tertentu; 4) Merangkum, yaitu mengemukakan satu kalimat yang mempresentasikan informasi yang diterima; 5) Menyimpulkan, yaitu menyertakan proses menemukan pola dalam sejumlah contoh; 6) Membandingkan, yaitu melibatkan proses mendeteksi persamaan dan perbedaan antara dua atau lebih objek; dan 7) Menjelaskan, yaitu ketika siswa dapat membuat dan menggunakan model sebab-akibat dalam sebuah sistem. Melalui kemampuan pemahaman tersebut akan membantu siswa memahami dan menjelaskan suatu (konsep). Penjelasan tersebut sejalan dengan Kilpatrick et al, 2001 dalam (Utami \& Anitra, 2019) kemampuan pemahaman konsep adalah kemampuan dalam memahami konsep saat pembelajaran.

Kenyataannya,

kemampuan pemahaman konsep IPA siswa masih tergolong rendah. Hal ini dibuktikan dengan data dari Trend in Internasional Mathematic and Science Study 2015 dalam Hadi \& Novaliyosi (2019: 2) bidang sains, Indonesia menduduki peringkat 44 dari 49 rata-rata skor Indonesia 397 dan jauh di bawah rata-rata internasional yaitu 500 . Hasil penelitian Widiawati et al. (2015) juga menunjukkan bahwa kemampuan pemahaman konsep IPA siswa di Sekolah Dasar masih rendah, ditunjukkan dengan sebanyak $10,81 \%$ peserta didik memperoleh nilai rata-rata dari tes pemahaman konsep IPA, sebanyak 45,95\% peserta didik memperoleh nilai dibawah ratarata dan sebanyak $43,24 \%$ peserta didik memperoleh nilai di atas rata-rata, sehingga perlu ditingkatkan.

Rendahnya kemampuan pemahaman konsep IPA siswa juga terjadi di MIS Ushuluddin Singkawang. Dari hasil observasi awal yang dilakukan, diperoleh bahwa kemampuan pemahaman konsep IPA siswa masih rendah. Hal ini ditunjukkan dengan hasil pemberian tes berupa soal pemahaman konsep IPA kepada siswa, rata-rata nilai yang didapat sebesar 55. Hal tersebut dapat berdampak buruk bagi peserta didik yang tidak paham konsep sehingga ada masalah pada pemahaman konsep peserta didik.

Berdasarkan informasi dari guru kelas $\mathrm{V}$, guru menyatakan bahwa siswa masih banyak yang belum paham tentang pelajaran IPA terutama apabila membahas tentang sebuah konsep pada materi panas dan perpindahannya. Adapun menurut peserta didik yang diwawancarai oleh peneliti, dalam proses pembelajaran guru hanya menggunakan model pembelajaran langsung, guru juga tidak mengajak peserta didik untuk melakukan praktikum. Proses pembelajaran IPA yang berlangsung juga masih berpusat pada guru Hal tersebut menyebabkan peserta didik kurang terlibat dalam kegiatan pembelajaran IPA. Ketika guru menjelaskan, guru kurang memberikan kesempatan kepada siswa untuk bertanya sehingga berdampak pada kurangnya pemahaman siswa akan infomasi yang diterimanya. Kondisi seperti ini dapat diatasi dengan menerapkan model pembelajaran yang tepat untuk pembelajaran IPA.

Pada pembelajaran IPA banyak modelmodel pembelajaran yang bisa digunakan pada proses pembelajarannya. Salah satunya yang dapat diterapkan adalah model pembelajaran Predict-Observe-Explain (POE). Menurut Juniari et al. (2014: 3), POE merupakan salah satu model yang dapat membantu mengaktifkan siswa dalam proses pembelajaran karena pada model ini peserta didik tidak hanya mendengarkan tetapi juga mengamati peristiwa yang terjadi. POE merupakan model pembelajaran yang memiliki tugas utama yang harus dijalankan siswa yaitu, memprediksi, mengamati, menjelaskan. Dari langkah-langkah tersebut dapat dijelaskan bahwa: (1) prediksi (predict), misalnya siswa mengamati demonstrasi perpindahan panas secara konduksi guru memegang batang besi yang dibakar dengan korek api dan siswa langsung memprediksi apa yang terjadi dengan batang besi tersebut dan tangan guru; (2) pengamatan (observe), misalnya siswa mencatat dan mempraktikannya dengan memegang besi yang dibakar korek api untuk membuktikan apakah prediksinya benar; (3) penjelasan (explain), misalnya siswa mengajukan prediksi mengenai pengamatan, misalnya prediksinya besi tersebut panas dan membuat tangan menjadi panas, jika prediksi dan praktiknya benar siswa merangkum dan 
menjelaskannya lebih lengkap, jika prediksi dan praktiknya berbeda siswa dapat menjelaskan perbedaan antara prediksi yang dibuat siswa dan hasil praktiknya.

Hubungan model pembelajaran POE dengan kemampuan pemahaman konsep IPA adalah guru menjelaskan materi menggunakan model pembelajaran POE sesuai indikator kemampuan pemahaman konsep IPA mulai dari menjelaskan, mencontohkan, membandingkan, mengklasifikasikan, menyimpulkan begitu juga siswa dalam pembelajaran siswa menjelaskan prediksinya, mencontohkan demonstrasi dengan contoh yang lain, membandingkan prediksinya dengan pengamatannya, mengklasifikasikan prediksi dengan demonstrasi, dan menyimpulkan hasil prediksi dan hasil pengamatan yang benar. Penelitian sebelumnya yang telah menerapkan model POE terhadap pemahaman konsep yaitu Nugraha et al. (2019) yang menunjukan bahwa model pembelajaran POE dapat meningkatkan pemahaman konsep IPA siswa. Perbedaan penelitian yang dilakukan oleh Nugraha et al. dengan penelitian ini adalah untuk mengetahui pengaruh moedel pembelajaran POE terhadap kemampuan pemahaman konsep IPA siswa dan untuk mengetaui perbedaan kemampuan pemahaman konsep IPA siswa setelah diterapkan model pembelajaran POE antara kelas eksperimen dengan kelas control. Selain itu, hasil penelitian Andriani et al. (2019) juga menunjukan bahwa penerapan model pembelajaran POE yang berorientasi Chemoentrepreneurship berpengaruh terhadap pemahaman konsep IPA siswa.

\section{METODE PENELITIAN}

Metode dalam penelitian ini quasi experimental design (eksperimen semu). Menurut Sugiyono (2015: 114), penelitian eksperimen semu adalah suatu cara untuk yang digunakan karena pada kenyataannya sulit mendapatkan kelompok kontrol yang digunakan untuk penelitian. Model ini dipakai untuk menguji hipotesis berbentuk hubungan sebab akibat melalui perlakuan dan menguji perubahan yang diakibatkan oleh perlakuan tersebut. Peneliti meneliti ada tidaknya pengaruh penerapan model pembelajaran Predict-Observe-Explain (POE) terhadap kemampuan pemahaman konsep ilmu pengetahuan alam (IPA) siswa yang terdapat dalam kelas eksperimen. Kelas eksperimen adalah kelas dengan perlakuan model POE dan kelas kontrol dengan model pembelajaran langsung. Perbedaan pemahaman pada kedua kelompok perlakuan dapat dilihat dengan dilakukan post-test setelah pembelajaran berakhir, tujuannya untuk mengetahui perubahan pemahaman konsep siswa kelas $\mathrm{V}$ setelah pembelajaran menggunakan model pembalajaran $\mathrm{POE}$.

Pada penelitian ini, peneliti menggunakan Post-test Only Control Design. Pada desain ini terdapat dua kelompok yaitu kelompok yang diberi perlakuan. Populasi adalah wilayah generalisasi yang terdiri atas obyek atau subyek yang mempunyai kualitas dan karakteristik tertentu yang ditetapkan oleh peneliti untuk dipelajari dan kemudian ditarik kesimpulannya (Sugiyono, 2015: 117). Populasi dalam penelitian ini adalah seluruh siswa kelas V MIS Ushuluddin Singkawang yang terdiri dari 2 kelas yaitu V A dan V B. Sampel adalah bagian dari jumlah dan karakteristik yang dimiliki oleh populasi (Sugiyono, 2015: 118). Teknik pengambilan sampel dalam penelitian ini adalah purposive sampling, yaitu teknik penentuan Sampel dengan pertimbangan tertentu (Sugiyono, 2015: 124). Kelas yang yang akan dijadikan sampel yaitu kelas $V$, yang terdapat 2 kelas yaitu kelas $\mathrm{V} A$ dan $\mathrm{V} B$. Setelah pengambilan sampel kelas yang terpilih sebagai kelas eksperimen dalam penelitian ini adalah kelas $\mathrm{V}$ A yang berjumlah 28 siswa, sedangkan kelas yang terpilih sebagai kelas kontrol adalah kelas $\mathrm{V}$ B dengan jumlah 28 siswa. Hal ini berdasarkan saran dari guru kelas $\mathrm{V}$ bahwa kelas VA dan kelas VB rata-rata nilainya sama-sama rendah.

Teknik pengumpulan data yang digunakan pada penelitian ini adalah teknik tes dan non tes. Tes yang digunakan adalah tes diagnostik berbentuk esai mengenai materi Panas dan Perpindahannya. Tes ini diberikan pada dua kelas sampel yaitu kelas eksperimen dan kelas kontrol. Tes di kelas eksperimen dilaksanakan sesudah model pembelajaran POE dilaksanakan berupa lembar tes post-test. Tes di kelas kontrol yang digunakan berupa non tes pembelajaran langsung. Setelah peneliti mengumpulkan data melalui tes langkah selanjutnya adalah menganalisis data. Analisis data sangat bervariasi bentuknya tergantung bagaimana data yang terkumpul akan diorganisasikan. Kegiatan analisis data berdasarkan variabel dari seluruh responden, mentabulasi data berdasarkan variable dari seluruh responden, menyajikan data tiap variabel yang diteliti, melakukan perhitungan untuk menguji hipotesis yang telah diajukan. Teknik analisis data yang digunakan dalam penelitian ini adalah analisis kuantitatif dan statistika. Pada penelitian ini akan diperoleh data kuantitatif sehingga untuk menganalisis data didapatkan dari pemberian tes pemahaman konsep dan penyebaran angket akan dilakukan teknik statistik. 
HASIL DAN PEMBAHASAN

Hasil Penelitian

Kemampuan Pemahaman Konsep IPA Siswa

Hasil dari pengumpulan data yang dilakukan selama penelitian di MIS Ushuluddin Singkawang adalah didapatkannya data hasil post-test siswa berupa skor dari kelas yang diajarkan model pembelajaran POE untuk kelas eksperimen dan model pembelajaran langsung untuk kelas kontrol terhadap kemampuan pemahaman konsep IPA siswa pada materi panas dan perpindahannya. Penilaian kemampuan pemahaman konsep IPA siswa dinilai dari skor rata-rata kemampuan pemahaman konsep IPA siswa, dengan skor maksimum 100. Adapun soal post-test yang diberikan kepada siswa berupa soal tes esai kemampuan pemahaman konsep IPA siswa yang memuat 5 indikator yaitu: (1) Menafsirkan (2) Mencontohkan (3) Mengklasifikasikan (4) Membandingkan (5) Menjelaskan. Setelah data dianalisis, maka diperoleh nilai rata-rata, standar deviasi, varians dan jumlah siswa kelas eksperimen dan kelas kontrol. Untuk selengkapnya disajikan nilai pada tabel 1 berikut:

Tabel 1. Rekapitulasi Nilai Siswa Kelas Eksperimen dan Kontrol

\begin{tabular}{ccccc}
\hline Kelas & $\begin{array}{c}\text { Rata } \\
\text {-rata } \\
(\overline{\boldsymbol{X}})\end{array}$ & $\begin{array}{c}\text { Stand } \\
\text { ar } \\
\text { Devia } \\
\text { si } \\
(\mathrm{SD})\end{array}$ & $\begin{array}{c}\text { Varian } \\
\mathrm{s}\left(\boldsymbol{S}^{2}\right)\end{array}$ & $\begin{array}{c}\text { Jumla } \\
\mathrm{h} \\
\text { siswa } \\
(\mathrm{n})\end{array}$ \\
\hline $\begin{array}{c}\text { Eksperim } \\
\text { en }\end{array}$ & 68 & 15,52 & $\begin{array}{c}240,8 \\
9\end{array}$ & 28 \\
\hline Kontrol & 49 & 18,41 & $\begin{array}{c}339,0 \\
5\end{array}$ & 28 \\
\hline
\end{tabular}

Rekapitulasi nilai siswa kelas eksperimen dan kelas kontrol di sajikan dalam bentuk diagram batang sebagai berkut:

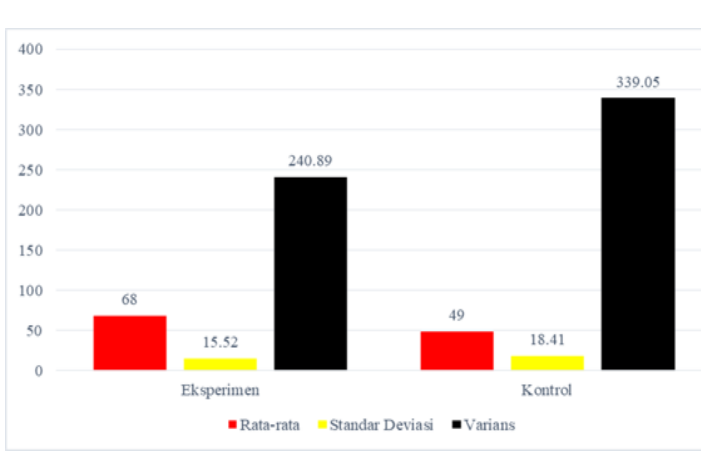

Gambar 1. Diagram Batang Nilai Siswa Kelas Kontrol dan Eksperimen

Berdasarkan data pada Gambar 1, terdapat perbedaan rata-rata untuk kemampuan pemahaman konsep IPA siswa antara kelas eksperimen dengan kelas kontrol dimana rata-rata skor kelas eksperimen terdapat nilai 68 , rata-rata skor kelas kontrol terdapat nilai 49 , nilai standar deviasi kelas eksperimen 15,52, kelas kontrol 18,41, nilai varians dari kelas eksperimen mendapatkan nilai 240,89 dan kelas kontrol 339,05. Maka selanjutnya untuk mengetahui pengaruh kemampuan pemahaman konsep IPA siswa secara signifikan antara kelas eskperimen dan kelas kontrol maka dilakukan uji perbedaan dua rata-rata kemampuan pemahaman konsep IPA siswa antara kelas eksperimen dan kelas kontrol.

\section{a. Uji rata-rata kelas eksperimen dan kelas kontrol}

Untuk mengetahui perbedaan kemampuan pemahaman konsep IPA siswa antara kelas eskperimen dan kelas kontrol pada materi panas dan perpindahannya kelas V MIS Ushuluddin menggunakan uji $\mathrm{t}$ dua sampel. Namun sebelumnya akan dilakukan uji normalitas dan homogenitas terlebih dahulu. Adapun uji normalitas dan homogenitas sebagai berikut.

\section{1) Uji normalitas}

Uji normalitas yang dilakukan dalam penelitian ini untuk menentukan skor data posttest yang telah dikumpulkan berdistribusi normal atau tidak. Hasil analisis uji normalitas data post-test kemampuan pemahaman konsep IPA siswa kelas eksperimen dan kelas kontrol dapat dilihat pada tabel 2 berikut ini:

Tabel 2. Hasil Perhitungan Uji Normalitas Data

\begin{tabular}{lcc}
\hline \multirow{2}{*}{ Statistika } & \multicolumn{2}{c}{ Kelas } \\
\cline { 2 - 3 } & Eksperimen & Kontrol \\
\hline$x^{2}{ }_{\text {hitung }}$ & 3,344 & 3,165 \\
\hline Jumlah siswa $(\mathrm{n})$ & 28 & 28 \\
\hline $\begin{array}{l}\text { Taraf } \\
(\alpha)\end{array}$ & $5 \%$ & $5 \%$ \\
\hline$x^{2}{ }_{\text {tabel }}$ & 7,814 & 7,814 \\
\hline Keputusan & \multicolumn{2}{c}{$H_{o}$ diterima } \\
\hline Kesimpulan & \multicolumn{2}{c}{ Normal } \\
\hline
\end{tabular}

Dari tabel 2 terlihat bahwa hasil perhitungan uji normalitas data pada kelas eksperimen didapatkan $x^{2}{ }_{\text {hitung }}$ yaitu 3,344 dan $x_{\text {tabel }}^{2}$ adalah 7,814. Karena $x^{2}{ }_{\text {hitung }} \leq$ $x^{2}{ }_{\text {tabel }}$ yaitu $3,344 \leq 7,814$ maka data berdistribusi normal. Sedangkan hasil perhitungan uji normalitas data pada kelas kontrol didapatkan $x^{2}{ }_{\text {hitung }}$ yaitu 3,165 dan $x^{2}{ }_{\text {tabel }}$ adalah 7,814. Karena $x^{2}{ }_{\text {hitung }} \leq x^{2}{ }_{\text {tabel }}$ yaitu $3,165 \leq 7,814$ maka data berdistribusi normal. Karena data kelas eksperimen dan kelas kontrol berdistribusi normal, maka untuk 
menentukan homogenitas data menggunakan rumus $f$.

\section{2) Uji homogenitas data menggunakan rumus $f$}

Setelah data skor post-test kelas eksperimen dan kelas kontrol dihitung dan didapatkan data tersebut berdistribusi normal, selanjutnya akan melakukan uji homogenitas data menggunakan rumus f. Adapun hasil perhitungan uji homogenitas data sebagai berikut:

Tabel 3. Hasil Perhitungan Uji Homogenitas

\begin{tabular}{lcc}
\hline \multirow{2}{*}{ Statistika } & \multicolumn{2}{c}{ Kelas } \\
\cline { 2 - 3 } & Eksperimen & Kontrol \\
\hline Varians $\left(s^{2}\right)$ & 240,89 & 337,81 \\
\hline$f_{\text {hitung }}$ & \multicolumn{2}{c}{1,402} \\
\hline Jumlah siswa $(\mathrm{n})$ & 28 & 28 \\
\hline Taraf kesukaran & $5 \%$ & $5 \%$ \\
$(\alpha)$ & \multicolumn{2}{c}{1,90} \\
\hline$f_{\text {tabel }}$ & \multicolumn{2}{c}{$H_{a}$ diterima } \\
\hline Keputusan & \multicolumn{2}{c}{ Homogen } \\
\hline Kesimpulan & \multicolumn{2}{c}{5} \\
\hline
\end{tabular}

Berdasarkan tabel 3. di atas, terlihat bahwa perhitungan data menggunakan rumus $f$. Diketahui varians kelas eksperimen yaitu 240,89 dan menjadi varians terkecil, sedangkan varinas kelas kontrol adalah 337,81 dan menjadi varians terbesar sehingga $f_{\text {hitung }}$ adalah 1,402. Dari f tabel dengan $\alpha=5 \%$ dan dk pembilang 27 dan $\mathrm{dk}$ penyebut 27 diperoleh $f_{\text {tabel }}=1,90$. Karena $f_{\text {hitung }}<f_{\text {tabel }}$ yaitu $1,402<1,90$ maka kelas eksperimen dan kelas kontrol mempunyai varians yang sama atau homogen. Karena data nilai pada kelas eksperimen dan kontrol berdistribusi normal dan homogen, maka selanjutnya dilakukan uji t dua sampel untuk mengetahui apakah terdapat pengaruh kemampuan pemahaman konsep IPA siswa antara kelas yang diberikan model pembelajaran POE dengan kelas yang diberikan pembelajaran langsung pada materi panas dan perpindahannya kelas V MIS Ushuluddin Singkawang.

\section{3) Uji perbedaan kelas eksperimen dan kontrol menggunakan uji t dua sampel}

Berdasarkan uji normalitas dan homogenitas diperoleh bahwa data post-test kelas eksperimen maupun kelas kontrol berdistribusi normal dan mempunyai varians yang sama atau homogen. Maka untuk menguji kesamaan rata-rata kedua kelas menggunakan uji t dua sampel. Berikut hasil perhitungan uji t dua sampel:
Tabel 4. Hasil Perhitungan Uji T Dua Sampel

\begin{tabular}{|c|c|c|c|c|c|c|}
\hline $\begin{array}{l}\text { Kelom } \\
\text { pok }\end{array}$ & $\begin{array}{l}d \\
k\end{array}$ & $\alpha$ & $t_{\text {hitung }}$ & $t_{\text {tabel }}$ & $\begin{array}{l}\text { Keputu } \\
\text { san }\end{array}$ & $\begin{array}{l}\text { Kesimp } \\
\text { ulan }\end{array}$ \\
\hline $\begin{array}{l}\text { Eksperi } \\
\text { men } \\
\text { dan } \\
\text { Kontrol }\end{array}$ & $\begin{array}{l}5 \\
4\end{array}$ & $\begin{array}{l}5 \\
\%\end{array}$ & 2,839 & 2,0048 & $\begin{array}{l}H_{a} \\
\text { diterim } \\
\text { a }\end{array}$ & $\begin{array}{l}\text { Terdapa } \\
\mathrm{t} \\
\text { perbeda } \\
\text { an } \\
\text { kemam } \\
\text { puan }\end{array}$ \\
\hline
\end{tabular}

Berdasarkan tabel 4. di atas, diketahui $t_{\text {hitung }}=2,839$ dan $t_{\text {tabel }}=2,00488$ diperoleh $t_{\text {hitung }}>t_{\text {tabel }}$ yaitu $2,839>2,00488$ maka $H_{a}$ diterima dan $H_{o}$ ditolak. Sehingga dapat disimpulkan bahwa terdapat perbedaan kemampuan pemahaman konsep IPA siswa antara kelas yang diberikan model pembelajaran POE dengan pembelajaran langsung pada materi panas dan perpindahannya kelas V MIS Ushuluddin Singkawang. Karena terdapat perbedaan maka ada pengaruh kemampuan pemahaman konsep IPA siswa antara kelas yang diberikan model pembelajaran POE dengan pembelajaran langsung pada materi panas dan perpindahannya kelas V MIS Ushuluddin Singkawang.

\section{Pembahasan \\ Perbedaan konsep IPA siswa \\ Penelitian ini dilaksankan di MIS} Ushuluddin Singkawang yang terdiri dari 2 kelas yaitu kelas eksperimen dan kelas kontrol. Kelas eksperimen berasal dari kelas $\mathrm{V} A$ yang terdiri dari 28 siswa, sedangkan kelas kontrol berasal dari kelas $\mathrm{V} B$ yang terdiri dari 28 siswa juga. Untuk kelas eksperimen diberikan model pembelajaran POE sedangkan kelas kontrol diberikan model pembelajaran langsung.

Setelah melakukan penelitian, peneliti memberikan soal post-test kepada siswa untuk melihat pengaruh kemampuan pemahaman konsep IPA siswa. Selanjutnya peneliti melakukan perhitungan terhadap hasil post-test siswa untuk melihat apakah kelas eksperimen yang diberikan perlakuan khusus yaitu menerapkan model pembelajaran POE mendapatkan hasil yang lebih baik dibandingkan kelas kontrol yang hanya diberikan perlakuan model pembelajaran langsung. Model pembelajaran POE dikembangkan untuk mengetahui kemampuan siswa dalam memprediksi suatu permasalahan. Hal tersebut sejalan dengan hasil penelitian (Prasetyo et al., 2019) yaitu model pembelajaran POE yang diawali dengan mengahadapkan siswa pada suatu prediksi permasalahan. Pernyataan tersebut di dukung dengan hasil penelitian Nugraha et al. (2019) yang menyatakan model pembelajaran $\mathrm{POE}$ dapat meningkatkan pemahaman konsep siswa 
karena kegiatan memprediksi siswa memperoleh konsep yang mereka pelajari. Sehingga saat selama proses pembelajaran siswa dapat menemukan permasalahan yang terjadi lewat kegiatan model tersebut dan mempengaruhi pemahaman konsep mereka.

Berdasarkan hasil perhitungan data post-test siswa didapatkan $t_{\text {hitung }}>t_{\text {tabel }}$ yaitu $2,839>2,00488$ sehingga terdapat pengaruh kemampuan pemahaman konsep IPA siswa antara kelas yang diberikan model pembelajaran POE dengan pembelajaran langsung pada materi panas dan perpindahannya kelas V MIS Ushuluddin Singkawang. Hal tersebut sejalan dengan hasil penelitian Nurliana et al. (2019) yang diketahui adanya perbedaan signifikan terhadap pemahaman Konsep IPA antara kelas yang menggunakan model pembelajaran POE (Predict, Observe, Explain) dengan kelas yang menggunakan pembelajaran langsung (Direct Instruction) kemampuan pemahaman konsep IPA siswa pada kelas eskperimen dan kelas kontrol disebabkan oleh perbedaan perlakuan antara dua kelas tersebut. Hasil penelitian Sudiadnyani et al. (2013) juga menyatakan bahwa terdapat perbedaan yang signifikan antara kemampuan pemahaman konsep IPA pada kelas yang menggunakan model pembelajaran POE dengan model pembelajaran langsung. Kemudian didukung pula dengan hasil penelitian Wiguna et al. (2018) yang menunjukkan terdapat perbedaan yang signifikan kemampuan pemahaman konsep antara kelas yang menggunakan model pembelajaran $\mathrm{POE}$ dengan kelas yang menggunakan model pembelajaran langsung.

\section{SIMPULAN DAN SARAN Simpulan}

Berdasarkan hasil perhitungan data penelitian dan pembahasan, dapat disimpulkan bahwa: 1). Model pembelajaran POE memiliki pengaruh terhadap kemampuan pemahaman konsep (Ilmu Pengetahuan Alam) IPA siswa pada materi panas dan perpindahannya kelas V MIS Ushuluddin Singkawang, 2). Terdapat perbedaan kemampuan pemahaman konsep IPA siswa menggunakan model pembelajaran POE dengan model pembelajaran langsung pada materi panas dan perpindahannya kelas $V$ di MIS Ushuluddin Singkawang, dan kemampuan pemahaman konsep IPA siswa kelas eksperimen lebih baik dari kelas control.

\section{Saran}

Berdasarkan hasil penelitian yang telah didapatkan, maka saran dalam penelitian ini sebagai berikut: 1). Bagi guru mata pelajaran IPA dapat menggunakan model pembelajaran
POE yang dapat membantu siswa dalam menyelesaikan soal yang berkaitan dengan pemahaman konsep IPA siswa khususnya pada materi panas dan perpindahannya, 2). Bagi peneliti penelitian ini sangat bermanfaat dalam menambah wawasan dan ilmu pengetauan tentang model pembelajaran IPA yang nantinya akan dijadikan bekal masa depan dalam mengajar di kelas, 3). Bagi peneliti yang selanjutnya akan melakukan penelitian tentang model pembelajaran $\mathrm{POE}$ sebaiknya melakukan penelitian yang lebih mendalam mengenai pengelolaan kelas dalam melihat pengaruh model pembelajaran $\mathrm{POE}$ terhadap kemampuan pemahaman konsep IPA siswa.

\section{UCAPAN TERIMAKASIH}

Ucapan terimakasih disampaikan kepada Kepala Madrasah, guru, dan siswa kelas V di MIS Ushuluddin Singkawang sehingga penelitian ini dapat dilakukan dengan baik. Kemudian ucapan terimakasih juga disampaikan kepada STKIP Singkawang yang telah memfasilitasi peneliti dalam menyelesaikan artikel ini.

\section{DAFTAR RUJUKAN}

Anderson, L. W., \& Krathwol, D. R. (2010). Kerangka Landasan Untuk Pembelajaran, Pengajaran, Asesmen Revisi Taksonomi Bloom. Pustaka Belajar.

Andriani, R., Muhali, M., \& Dewi, C. A. (2019). Pengaruh Model Pembelajaran POE (Predict-Observe-Explain) Berorientasi Chemoentrepreneurship Terhadap Pemahaman Konsep Siswa Pada Materi Larutan Penyangga. Hydrogen: Jurnal Kependidikan Kimia, 5(2), 94. https://doi.org/10.33394/hjkk.v5i2.1649

Hadi, S., \& Novaliyosi. (2019). TIMSS Indonesia (Trends in International Mathematics and Science Study). Prosiding Seminar Nasional \& Call For Papers Program Studi Magister Pendidikan Matematika Universitas Siliwangi, 562-569.

Juniari, N. K., Kusmariyatni, N. N., \& Margunayasa, I. G. (2014). Pengaruh Model Pembelajaran Poe Dan Motivasi Belajar Terhadap Hasil Belajar Ipa Siswa Kelas V Sd. Jurnal Mimbar PGSD Universitas Pendidikan Ghanesha, 9(5), $1-12$.

Mariana, I. M. A., \& Praginda, W. (2009). Hakikat IPA dan Pendidikan IPA. Pusat Pengembangan dan Pemberdayaan Pendidik dan Tenaga Kependidikan IImu Pengetahuan Alam (PPPPTK IPA).

Nugraha, D. A., Dimas, A., Cari, C., Suparmi, A., \& Sunarno, W. (2019). Meta Analisis 
Pengaruh Model Pembelajaran POE Terhadap Pemahaman Konsep. Prosiding SNFA (Seminar Nasional Fisika Dan Aplikasinya), 4, 174. https://doi.org/10.20961/prosidingsnfa.v4i 0.37768

Nurliana, A., Rodiyana, R., \& Haryanti, Y. D. (2019). Pengaruh Model Pembelajaran POE (Predict, Observe, Explain) terhadap Pemahaman Konsep IPA Siswa Sekolah Dasar. Seminar Nasional Pendidikan FKIP UNMA, 776-786.

Prasetyo, R. I., Hidayat, N., \& Dimas, A. (2019). Studi Literature Model Pembelajaran POE. Penguatan Pendidikan \& Kebudayaan Untuk Menyongsong Society 5.0, 704710.

Pt, N., Muliawati, C., Ardana, I. K., \& Negara, I. G. A. O. (2013). PENGARUH MODEL PEMBELAJARAN PREDICT-OBSERVEEXPLAIN TERHADAP HASIL BELAJAR IPA SISWA KELAS V SD DI GUGUS UBUD Jurusan Pendidikan Guru Sekolah Dasar , FIP Universitas Pendidikan Ganesha Dewasa ini negara Indonesia.

Sudiadnyani, P., Sudana, D. N., \& Garminah, N. N. (2013). Pengaruh Model Pembelajaran Predict-Observe-Explain (POE) terhadap Pemahaman Konsep IPA Siswa Kelas IV SD Kelurahan Banyuasri. Mimbar PGSD Undiksha, 1(1), 1-10.

Sugiyono. (2015). Metode Penelitian Pendidikan Pendekatan Kuantitatif, Kualitatif, dan $R \& D$. Alfabeta.

Utami, C., \& Anitra, R. (2019). MATA KULIAH MATEMATIKA SD Students Mathematical Understanding Ability Based on Initial Ability in Mathemics for Elementary Sochool Subject. 11(02), 103-110.

Widiawati, N. P., Pudjawan, K., \& Margunayasa, I. G. (2015). Analisis pemahaman konsep dalam pembelajaran IPA pada siswa kelas IV SD di gugus II kecamatan banjar. EJournal PGSD Universitas Pendidikan Ganesha, 3(1), 12-14. https://ejournal.undiksha.ac.id/index.php/ JJPGSD/article/view/5847

Wiguna, C. S., Sumaatmadja, N., \& Ningrum, E. (2018). Pengaruh Model Pembelajaran POE Terhadap emahaman Konsep dan Kemampuan Berpikir Kreatif Peserta Didik. Geografi Gea, 13 (1). 